\title{
The growth of three varieties of black pepper (Piper nigrum) under different light intensities related to indigenous hormones role
}

\author{
ISSUKINDARSYAH ${ }^{1,2}$, ENDANG SULISTYANINGSIH ${ }^{1, \bullet}$, DIDIK INDRADEWA ${ }^{1}$, \\ EKA TARWACA SUSILA PUTRA ${ }^{1}$ \\ ${ }^{1}$ Department of Agronomy, Faculty of Agriculture, Universitas Gadjah Mada. Jl. Flora No. 1, Bulaksumur, Sleman 55281, Yogyakarta, Indonesia. \\ Tel./fax.: +62-274-563062, "email: endangsih@ugm.ac.id \\ ${ }^{2}$ Assessment Institute of Agricultural Technology, Kepulauan Bangka Belitung, Indonesian Agency for Agricultural Research and Development, Ministry \\ of Agriculture. Jl Mentok Km 4, Pangkalpinang, Kabupaten Bangka 33134, Kepulauan Bangka Belitung, Indonesia
}

Manuscript received: 26 December 2019. Revision accepted: 3 April 2020.

\begin{abstract}
Issukindarsyah, Sulistyaningsih E, Indradewa D, Putra ETS. 2020. The growth of three varieties of black pepper (Piper nigrum) under different light intensities related to indigenous hormones role. Biodiversitas 21: 1778-1785. Low light intensity causes the alteration of plant biochemical and morphological as the mechanism of adaptation. The experiment used split-plot design with three replications. The main plots were three light intensity levels, i.e. $100 \%, 75 \%$, and $50 \%$ radiation; while subplots were three varieties namely Nyelungkup, Petaling 1 and Petaling 2. This research was conducted to figure out the effect of shadings on hormones and the growth of three varieties of black pepper (Piper nigrum L.). The results showed that in initial vegetative growth, varieties of Nyelungkup and Petaling 1 had higher growth of both ortotroph and plagiotroph branches, leaf number, leaf area, length of root, root surface area, plant dry weight, nett assimilation rate, and plant growth rate than the variety of Petaling 2 . The light intensity of $50 \%$ and $75 \%$ increased the auxin and gibberellin contents of the leaf but they did not affect the zeatin. The maximum gibberellin and auxin contents of leaf were recorded at $75 \%$ light intensity. The $50 \%$ and $75 \%$ light intensity raised the length, diameter, and internode of ortotroph branch; number, length, and internode of plagiotroph branch; leaf number; leaf area; leaf area ratio; length of root; root surface area; plant growth rate and plant dry weight related to indigenous hormones role.
\end{abstract}

Keywords: Black pepper varieties, growth, hormones, light intensities, morphology

\section{INTRODUCTION}

Black pepper (Piper nigrum L.) is a perennial climbing crop, so it requires supporting poles for good growth and production. One of common-used poles is stem of living tree (living support). In addition to more economical, the living support is able to play a role as land conservation such as in creating better life for beneficial microorganisms, minimizing runoff and providing green fertilizers as source of organic matter. However, the cultivation of black pepper with living supports encounters many constraints so that its growth and yield are lower than those with nonliving (deadwood) poles (Wahid 1984). One of factors contributing to lower yield in black pepper with living support is low light intensity (Yudianto et al. 2014).

The use of shade-resistant variety can improve the growth and yield of black pepper using living supports. The information about response and resistance on black pepper variety against shadings is not widely reported. In Indonesia, there are three superior varieties of commoncultivated black pepper, i.e. Petaling 1, Petaling 2 and Nyelungkup. They have different morphological characters so it is assumed that they have dissimilar response and adaptation levels against various light intensity levels.

Plant adaptation on lower light intensity is responded with some mechanisms such as the change in morphological structure (Gong et al. 2015). According to Casal (2012), the mechanisms of plant resistance against shadings were documented in two methods, namely shadetolerant and shade-avoidance. Shade-tolerant plants display the morphological, anatomy and architecture traits enabling it increases the light interception and adsorption, like high leaf area ratio and specific leaf area (Gommers et al. 2013). In addition, they tend to have low growth rate and thinner leaf as well as decrease apical dominance and large branch number (Martinez-Garcia et al. 2010). In order to avoid the shading, plants raise hight, length of internode, petiole elongation and leaf insertion angle; reduce the branching; and accelerate leaf senescence and flowering (Casal 2013).

The change in morphology due to the alteration of light environment is related to dynamics of plant indigenous hormones. According to Casal (2012), the signal of low light increased the expression of gene synthesizing auxin, gibberellin, and brassinosteroid. The expression of gene for biosynthesis was of auxin on arabidopsis plant increases under low light intensity ( $\mathrm{Li}$ et al. 2012). The increment of gibberellin and auxin due to low light intensity was also reported on soybean (Glycine max) (Wu et al. 2017) and sweet potato (Ipomoea batatas) leaves (Wang et al. 2013).

The response of black pepper on shading has been reported by Wahid (1984) in which slight shading provides positive effect on growth and yield on black pepper varieties of Belantung and Lampung Daun Lebar. Furthermore, it is noted that $25 \%-50 \%$ shadings generate significant increment on length of ortotroph branch, number of plagiotroph branches and leaf number of black 
pepper after seven-month planting. However, heavy shadings inhibit growth and decrease plant production. Number of plagiotroph branch and leaf number of Belantung variety under 50-75\% shadings (Wahid 1984). Such information is still limited and important to know the response of some varieties and the role of hormones on morphological change under several shading levels. This research is conducted to figure out the effect of shadings on hormones and growth of several varieties of black pepper (Piper nigrum L.).

\section{MATERIALS AND METHODS}

\section{Study area}

The study was carried out on July-December 2017 in Kemuja Village, Sub-district of Mendobarat, District of Bangka, Province of Kepulauan Bangka Belitung, Indonesia (Figure 1). The experiment was demonstrated under split-plot design with three replications. The main plot was light intensity levels and subplot was black pepper varieties. Three varieties of black pepper plant, i.e. Petaling 1, Petaling 2 and Nyelungkup, were planted in the field under three light intensity levels, namely $100 \%, 75 \%$, and $50 \%$. The light intensities were regulated by making a shade from black polynet. The light intensity of $100 \%$, $75 \%$ and $50 \%$ covered by a shade $0 \%, 25 \%$ and $50 \%$, respectively. The light intensity levels of treatments were continuously applied for five months.

The shading was made from black polynet with $2 \mathrm{~m}$ in height from soil surface and treatment plot of $5 \times 9 \mathrm{~m}$ in dimension. One-node and 5-month old cuttings of black pepper were planted with planting distance of $80 \times 80 \mathrm{~cm}$. They were supported by deadwood poles with $1.5 \mathrm{~m}$ in height. The plants were fertilized according to Wahid (1984) namely $25 \mathrm{~g}$ NPK (12: 12: 17) per plant for each distribution of fertilizer. Fertilization was implemented for five times. Other maintenance measures were weed control, binding of ortotroph branch as well as pest and disease management following field condition.

\section{Procedure}

Some parameters were recorded, such as microclimates, auxin, gibberellin and zeatin, morphological characteristics of the branch, leaf, and root as well as plant dry weight and plant growth analysis. The intensity of sunlight was observed every week using lux meter. At the same time, the temperature and air humidity were recorded using termohigrometer. The hormones and plant morphological characteristics, such as branch, leaf, and root were noticed five months after planting. The auxin, gibberellin and zeatin hormones were analyzed using method of Linskens and Jackson (1987). A total of $5 \mathrm{~g}$ of black pepper fresh leaves was ground using liquid nitrogen in mortal and then homogenized with $20 \mathrm{ml}$ of $65 \%$ of $\mathrm{MeOH}$. The extracts were centrifuged at 4,000 rpm for $30 \mathrm{~min}$. The supernatant was filtered using miliphore. A total of 5-10 $\mu \mathrm{l}$ of supernatant was injected using HPLC using mobile phase of $\mathrm{MeOH} 65 \%, \mathrm{C} 18$ Column at $40^{\circ} \mathrm{C}$, flow rate of mobile phase about $0.5 \mathrm{ml} / \mathrm{min}$ and injection pressure at $900 \mathrm{psi}$ and then detected using UV-VIS (Shimadzu DGU-20A5) at wavelength of $254 \mathrm{~nm}$. The contents of auxin, gibberellin, and zeatin were calculated using the formula:

\section{Content of auxin/gibberellin/zeatin $=$ \\ Width of sample area in chromatogram Width of standard area}

Leaf area, as well as length and area of root surface, were measured using leaf area meter. Dry weight of leaf, branch, and root was obtained by heating them at $65^{\circ} \mathrm{C}$ for $48 \mathrm{~h}$ in oven or until their weight was constant. Plant growth analyses included:

Leaf area ratio (LAR) $\left(\mathrm{cm}^{2} \mathrm{~g}^{-1}\right)$

$\mathrm{LAR}=\frac{\mathrm{La}}{\mathrm{W}}$

Nett Assimilation Rate (NAR) $\left(\mathrm{g} \mathrm{dm}^{-2}\right.$ week $\left.^{-1}\right)$

$\mathrm{NAR}=\frac{\mathrm{W} 2-\mathrm{W} 1}{\mathrm{~T} 2-\mathrm{T} 1} \times \frac{\ln \mathrm{La} 2-\ln \mathrm{La} 1}{\mathrm{La} 2-\mathrm{La} 1}$

Crop Growth Rate (CGR) $\left(\mathrm{g} \mathrm{m}^{-2}\right.$ week $\left.^{-1}\right)$

$\mathrm{CGR}=\frac{1}{\mathrm{Ga}} \times \frac{\mathrm{W} 2-\mathrm{W} 1}{\mathrm{~T} 2-\mathrm{T} 1}$

Where: Ga: ground area, W: plant dry weight, W1: plant dry weight at first destructive $(\mathrm{g})$, W2: plant dry weight at second destructive (g), T1: plant age at first destructive (week), T2: plant age at second destructive (week), La1: leaf area at first destructive $\left(\mathrm{dm}^{2}\right)$; La2: leaf area at second destructive $\left(\mathrm{dm}^{2}\right)$. The first destructive was done at twenty weeks after planting and the second destructive at twenty-five weeks after planting.

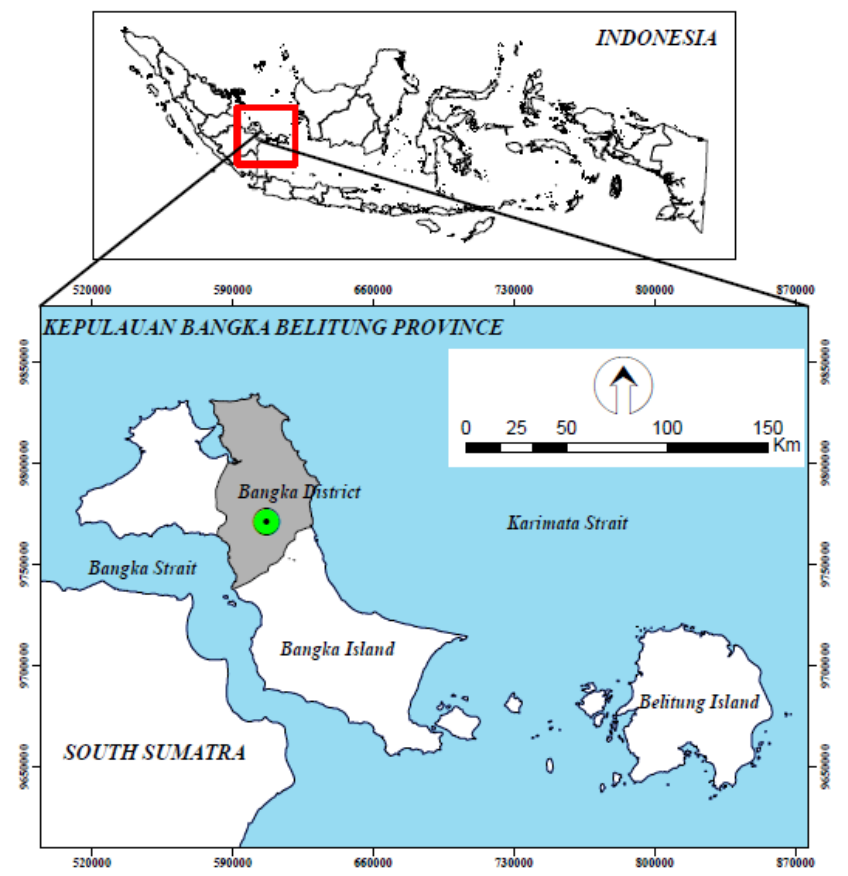

Figure 1. Location of (॰) Kemuja Village, Mendobarat Sub-district, Bangka District, Province of Kepulauan Bangka Belitung, Indonesia 


\section{Data analysis}

Data were statistically analyzed with ANOVA to recognize the interaction between two treatment factors. The significant difference was continued with HSD Tukey test at 5\% level. The correlation test to determine the relationship between auxin and gibberellin with plant morphology. The statistical analysis uses SAS 9.4 program.

\section{RESULTS AND DISCUSSION}

\section{Microclimate}

Microclimates including incidence of light intensity, temperature and air humidity at every light intensities level during this experiment were presented in Table 1 . The means incidence of light intensity of $100 \%, 75 \%$ and $50 \%$ were 68,000 lux, 48,000 lux and 32,000 lux, respectively. Light contained a number of photon energy generating heat so that it affected the temperature and air humidity. Air temperature and air humidity were relatively same under all light intensity levels. Air temperatures in the morning and noon were above optimum temperature for the growth of black pepper whereas that in the afternoon was in the optimum range. According to Nair (2011), the optimum temperatures for optimum growth of black pepper were in ranges of 21$27^{\circ} \mathrm{C}, 25-32^{\circ} \mathrm{C}$ and $24-30^{\circ} \mathrm{C}$ in the morning, noon and afternoon, respectively. Furthermore, it was explained that Air humidity at the noon was over the optimum for the growth of black pepper while those in the morning and afternoon were in optimum ranges. Optimum humidity for the growth of black pepper was $60-80 \%$ in range.

\section{Hormone content}

Signal of light intensity impacted hormonal biosynthesis. It was indicated by the different contents of gibberellin and auxin among light intensity levels but the content of zeatin was similar. The results showed that the content of leaf gibberellin was influenced by the interaction of variety and light intensity levels (Table 2). The 50\% and $75 \%$ light intensity increased the content of gibberellin on three varieties of black pepper. Light intensity of $75 \%$ raised up the content of leaf gibberellin on varieties of Nyelungkup and Petaling 1, however light intensity of 50\% reduced the content of gibberellin in which its value was not significantly different with $100 \%$. Dissimilar to the other two varieties, the content of gibberellin on Petaling 2 was not affected by shading. It revealed that the increment on content of leaf gibberellin of black pepper was not directly proportional to the decrease of light intensity. According to Casal (2013), the expression of genes for biosynthesis of gibberellin was sensitive against light alteration. The change of signal on light intensity was received by phytochrome of photoreceptor. Phytochrome was the pigment of protein on photoreceptors for red and far-red light, therefore the quantity in ratio of red and farred light (R: Fr) determined the number of light absorption by phytochrome (Possart et al. 2014). The increase of gibberellin content occurred since phytochrome induced the expression of GA 20-oxidases and GA $3^{\beta}$-hydroxylase genes (Yamaguchi et al. 1998). GA 20-oxidases converted GA 53 into GA 20 whereas GA $3^{\beta}$-hydroxylase converted GA 20 into GA 1 (Kamiya and Martinez-Garcia, 1999).

The content of leaf auxin was not affected by interaction of varieties and light intensity levels. The content of auxin was similar among varieties but it was significantly different among light intensity levels. Plants under $50 \%$ and $75 \%$ light intensities synthesized higher auxin than those $100 \%$ light intensity. The highest auxin content was synthesized by plants under light intensity of $75 \%$. Auxin content decreased at $50 \%$ light intensity but it was still above the content under 100\% light intensity (Table 3). Induction of auxin synthesis at low light intensity had been reported on Ipomoea batatas (L.) Lam, and Vitis vinifera (Wang et al. 2014; GonzaÂlez et al. 2016). Similar to gibberellin, stimulation of auxin synthesis at low light intensity was determined by activity of phytochrome. Rapid biosynthesis of auxin was required on the shade avoidance response also and its transport to promote elongation growth ( $\mathrm{Li}$ et al. 2012). According to Tao et al. (2008) and Halliday et al. (2009), the induction of auxin synthesis by phytochrome passed two ways, namely suppressing the expression of SUR2 gene and increasing the expression of TAA1 gene. Furthermore, It was explained that SUR2 was gen inducing enzyme of cytochrome P450 monooxygenase CYP83B1 forming indole glucosinolate while TAA1 was enzyme of tryptophan aminotransferase converting tryptophan into indole-3-acetic acid (IAA). Synthesis of auxin through TAA1 was the main pathway to increase the content of auxin in responding to the alteration of light environment (Tao et al. 2008).

Table 1. Light intensity incidence, temperature and air humidity at several illumination levels

\begin{tabular}{|c|c|c|c|}
\hline $\begin{array}{c}\text { Treatments } \\
\text { (light intensity levels }(\%)) \\
\end{array}$ & Light intensity incidence (Lux) & Temperature $\left({ }^{\circ} \mathrm{C}\right)$ & Air humidity (\%) \\
\hline \multicolumn{4}{|l|}{ Morning (07.00 am-08.00 am) } \\
\hline 100 & $33,328.96 \pm 2,039.39$ & $30.52 \pm 0.40$ & $68.24 \pm 1.84$ \\
\hline 75 & $21,995.03 \pm 1,374.60$ & $30.22 \pm 0.37$ & $68.54 \pm 1.79$ \\
\hline 50 & $14,893.10 \pm 938.73$ & $29.90 \pm 0.37$ & $68.77 \pm 1.80$ \\
\hline \multicolumn{4}{|l|}{ Noon (11.30 am-12.30 pm) } \\
\hline 100 & $83,660.57 \pm 4,862.16$ & $35.33 \pm 0.28$ & $37.84 \pm 1.43$ \\
\hline 75 & $61,436.32 \pm 3,796.03$ & $35.01 \pm 0.24$ & $39.40 \pm 1.29$ \\
\hline 50 & $40,953.90 \pm 2,770.07$ & $34.37 \pm 0.32$ & $40.43 \pm 1.86$ \\
\hline \multicolumn{4}{|l|}{ Afternoon (16.00 pm-17.00 pm) } \\
\hline 100 & $18,943.54 \pm 2,822.27$ & $30.72 \pm 0.66$ & $66.91 \pm 2.97$ \\
\hline 75 & $13,588.87 \pm 2,057.91$ & $30.55 \pm 0.60$ & $66.95 \pm 2.93$ \\
\hline 50 & $8,889.79 \pm 1,260.23$ & $30.31 \pm 0.59$ & $67.07 \pm 2.91$ \\
\hline
\end{tabular}


Table 2. Content of leaf gibberellin $\left(\mathrm{ng} \mathrm{g}^{-1}\right)$ on three varieties of black pepper at several light intensity levels

\begin{tabular}{|c|c|c|c|c|}
\hline \multirow{2}{*}{$\begin{array}{c}\text { Light intensities } \\
(\%)\end{array}$} & \multicolumn{3}{|c|}{ Varieties } & \multirow{2}{*}{ - Average } \\
\hline & Nyelungkup & Petaling 1 & Petaling 2 & \\
\hline 100 & $0.510 \mathrm{~d}$ & $0.635 \mathrm{~cd}$ & $0.885 \mathrm{bcd}$ & 0.677 \\
\hline 75 & $2.238 \mathrm{a}$ & $1.779 \mathrm{ab}$ & $1.725 \mathrm{ab}$ & 1.914 \\
\hline 50 & $0.540 \mathrm{~d}$ & $0.655 \mathrm{~cd}$ & $1.590 \mathrm{abc}$ & 0.928 \\
\hline Average & 1.093 & 1.023 & 1.400 & $(+)$ \\
\hline
\end{tabular}

Note: Numbers followed by similar letters on the same column and row were not significantly different at $5 \%$ level. $(+)=$ There was interaction

Table 3. Contents of leaf auxin and zeatin on black pepper under treatments of varieties and light intensity levels

\begin{tabular}{lll}
\hline \multirow{2}{*}{\multicolumn{1}{c}{ Treatment }} & \multicolumn{2}{c}{ Hormone $\left(\mathbf{n g ~ g}^{-\mathbf{1}}\right)$} \\
\cline { 2 - 3 } & \multicolumn{1}{c}{ Zeatin } \\
\hline Varieties & $2.49 \mathrm{a}$ & $0.08 \mathrm{a}$ \\
Nyelungkup & $2.17 \mathrm{a}$ & $0.08 \mathrm{a}$ \\
Petaling 1 & $2.75 \mathrm{a}$ & $0.09 \mathrm{a}$ \\
Petaling 2 & & \\
Light intensities (\%) & $1.59 \mathrm{c}$ & $0.09 \mathrm{a}$ \\
100 & $3.65 \mathrm{a}$ & $0.08 \mathrm{a}$ \\
75 & $2.17 \mathrm{~b}$ & $0.09 \mathrm{a}$ \\
50 & $(-)$ & $(-)$ \\
Interaction & & \\
\hline
\end{tabular}

Note: Numbers followed by similar letters on the same column were not significantly different at $5 \%$ level. $(-)=$ No interaction

Table 4. Leaf number on three varieties of black pepper at several light intensity levels

\begin{tabular}{|c|c|c|c|c|}
\hline \multirow{2}{*}{$\begin{array}{c}\text { Light intensities } \\
(\%)\end{array}$} & \multicolumn{3}{|c|}{ Varieties } & \multirow[b]{2}{*}{ Average } \\
\hline & Nyelungkup & Petaling 1 & Petaling 2 & \\
\hline 100 & 39.17ed & 34.67ed & $20.00 \mathrm{e}$ & 31.28 \\
\hline 75 & $134.33 \mathrm{a}$ & 114.33ab & $50.00 \mathrm{c}-\mathrm{e}$ & 99.55 \\
\hline 50 & $94.17 \mathrm{a}-\mathrm{c}$ & $75.00 \mathrm{~cd}$ & $63.67 \mathrm{~b}-\mathrm{e}$ & 77.61 \\
\hline Average & 89.22 & 74.67 & 44.56 & + \\
\hline
\end{tabular}

Note: Numbers followed by similar letters on the same column and row were not significantly different at $5 \%$ level. $(+)=$ Interaction

Table 5. Leaf area $\left(\mathrm{cm}^{2}\right)$ on three varieties of black pepper at several light intensity levels

\begin{tabular}{lllll}
\hline \multirow{2}{*}{$\begin{array}{c}\text { Light intensities } \\
(\%)\end{array}$} & \multicolumn{4}{c}{ Varieties } \\
\cline { 2 - 5 } & Nyelungkup & Petaling 1 & Petaling 2 & \\
\hline 100 & $926.20 \mathrm{~b}-\mathrm{d}$ & $703.20 \mathrm{~cd}$ & $371.70 \mathrm{~d}$ & 667.03 \\
75 & $3,559.50 \mathrm{a}$ & $3,274.40 \mathrm{a}$ & $1,362.30 \mathrm{a}-\mathrm{d}$ & $2,731.90$ \\
50 & $2,550.20 \mathrm{ab}$ & $1,840.60 \mathrm{a}-\mathrm{c}$ & $2,470.70 \mathrm{ab}$ & $2,287.17$ \\
Average & $2,345.30$ & $1,939.40$ & $1,401.57$ & + \\
\hline
\end{tabular}

Note: Numbers followed by similar letters on the same coloumn and row were not significantly different at 5\% level. $(+)=$ Interaction
Table 6. Leaf area ratio (LAR) $\left(\mathrm{cm}^{2} \mathrm{~g}^{-1}\right)$ on three varieties of black pepper at several light intensity levels

\begin{tabular}{llllll}
\hline \multirow{2}{*}{\begin{tabular}{c} 
Light intensities \\
\cline { 2 - 5 }
\end{tabular}} & \multicolumn{4}{c}{ Varieties } & \multirow{2}{*}{ Nyelungkup } \\
\cline { 2 - 5 } & Petaling 1 & Petaling 2 & \\
\hline 100 & $48.076 \mathrm{bc}$ & $56.201 \mathrm{a}-\mathrm{c}$ & $35.874 \mathrm{c}$ & 46.717 \\
75 & $61.413 \mathrm{a}-\mathrm{c}$ & $71.189 \mathrm{ab}$ & $67.077 \mathrm{a}-\mathrm{c}$ & 66.559 \\
50 & $64.280 \mathrm{a}-\mathrm{c}$ & $56.706 \mathrm{a}-\mathrm{c}$ & $86.207 \mathrm{a}$ & 69.064 \\
Average & 57.923 & 61.365 & 63.053 & + \\
\hline
\end{tabular}

Note: Numbers followed by similar letters on the same column and row were not significantly different at $5 \%$ level. $(+)=$ Interaction

The content of leaf zeatin was not affected by light intensities, it's expected because of the zeatin content of leaf was low. According to Zdarska et al. (2015), that light is an important factor controlling cytokinin biosynthesis. It has reported by Kohler et al. (1980) that the cytokinin content of amaranthus was significantly affected by light. Therefore in further research, it's necessary to analyze the zeatin content of branches and roots. Hammerton et al. (1998) reported, branch cytokinins content of Phaseolus vulgaris seedlings was higher than leaves and roots as well as influenced by light.

\section{Plant morphology \\ Leaf}

Leaf number, leaf area, and leaf area ratio were affected by interaction of variety and light intensity (Table 4,5 , and 6). Light intensity up to $50 \%$ increased leaf number, leaf area and leaf area ratio on black pepper. Leaf number and leaf area on varieties of Nyelungkup and Petaling 1 were maximum at $75 \%$ light intensity while those three parameters on a variety of Petaling 2 tended to increase at low light intensity up to $50 \%$. This information was parallel with the report of Kim et al. (2011) that leaf morphology on blueberry was significantly different among light intensity levels and it was higher on lower light intensity. Shape and dimension of leaf were the important factors affecting the absorption of sunlight. A plant having largest leaf number or leaf area absorbed more light intensity. Three variety of black pepper tested generated the leaf number and leaf area the same at 50\% light intensity so that probably had the same adaptability under low light intensity. The value of leaf area ratio on Nyelungkup and Petaling 2 tended to rase up to $50 \%$ light intensity. Different from Petaling 1, the leaf area ratio was maximum at a $75 \%$ light intensity and decrease at 50\% light intensity. There was not significantly different leaf area ratio of three varieties tested among at 50\% light intensity with $75 \%$ light intensity.

\section{Ortotroph and plagiotroph branches}

The growth of ortotroph and plagiotroph branches was not affected by interaction of s variety and light intensity. Morphological characteristics of ortotroph branch were different among varieties, excluding the length of internodes. There was different dimension of ortotroph dimension between Nyelungkup and Petaling 1 varieties, while Petaling 2 tended to have smaller morphological 
dimension than two other varieties. The growth of ortotroph and plagiotroph branches was significantly influenced by light intensity. Length, diameter and length of internode on ortotroph increased up to $75 \%$ light intensity, but the decrement of light intensity to $50 \%$ did not increase the length, diameter of internode and length of internode on ortotroph even they tended to reduce (Table 7).

There was no difference in number of plagiotroph branches and length of internode on plagiotroph among tested varieties. Length of plagiotroph on Nyelungkup variety was not different from that of Petaling 1 and that Petaling 1 was not different from Petaling 2. However, plagiotroph branch on Nyelungkup was longer than that of Petaling 2. The light intensity until $75 \%$ increased the number and length of plagiotroph branch. The decrement of further light intensity to $50 \%$ did not increase the number and length of plagiotroph even they tended to decrease. Light intensity levels did not provide different effects on length of internode on plagiotroph branch (Table 7).

Similar findings were reported by Wahid (1984) that light intensity up to $50 \%$ generated significant effect on length of ortotroph branch and number of plagiotroph branch. Cagnola et al. (2012) reported that low light intensity also increased stem growth, internode length, and leaf area tomato. Light intensity less than $50 \%$ or light intensity less than 32,000 lux had the potential in inhibiting the growth of branch. The growth of ortotroph and plagiotroph branches was the mechanism in adaptation against low light intensity. The length of ortotroph and plagiotroph branches, as well as the number of plagiotroph branches, increased by $68 \% .54 \%$ and $62 \%$, respectively compared to the plants under full light intensity.

The increase in growth of branch was parallel with the increment of auxin content. The content of auxin about $2.17 \mathrm{ppm}$ under $50 \%$ shading maximumly increased the growth of ortotroph and plagiotroph branches. The increment of auxin content around 3.65 ppm under $75 \%$ light intensity did not significantly increase the growth of branch on black pepper. The content of zeatin was relatively similar among light intensities while auxin was different so that the ratio of zeatin and auxin changed. Under $100 \%$ light intensity, the ratio of auxin and zeatin was the lowest and it increased at $75 \%$ light intensity.
Under 50\% light intensity, this ratio decreased again. The content of zeatin was lower than auxin indicated that the growth of shoot was more dominant than roots.

\section{Root}

The length of root and root area surface was not affected by interaction of variety and light intensity. Variety of Nyelungkup had the highest length and root area surface and the lowest ones were documented on variety of Petaling 2. The length and root area surface of Petaling 1 variety were not significantly different from those of Nyelungkup and Petaling 2 varieties. Plants under low light intensity (50\% and $75 \%$ ) produced larger length and root area surface than full light intensity (100\%) plants. The length and root area surface were maximum at $75 \%$ light intensity but they were not significantly different with $50 \%$ light intensity (Table 8). Such as on branches, root growth was controlled by hormonal balance especially ratio of zeatin and auxin. Content of zeatin was constant among shadings whereas auxin changed so that ratio of zeatin and auxin changed as well. Under $100 \%$ light intensity, ratio of auxin and zeatin was lower and increased at $75 \%$ light intensity. Ratio of zeatin and auxin decreased again at $50 \%$ light intensity but it was relatively higher than that of $100 \%$ light intensity. The zeatin content was lower than auxin content indicated that the growth of roots was lower than shoot.

Table 8. Length of root and root surface area on three varieties of black pepper at several light intensity levels

\begin{tabular}{lll}
\hline \multicolumn{1}{c}{ Treatment } & \multicolumn{1}{c}{$\begin{array}{c}\text { Root length } \\
(\mathbf{c m})\end{array}$} & $\begin{array}{c}\text { Root surface area } \\
\left(\mathbf{c m}^{2}\right)\end{array}$ \\
\hline Varieties & & \\
$\quad$ Nyelungkup & $44.46 \mathrm{a}$ & $1,919.30 \mathrm{a}$ \\
Petaling 1 & $28.48 \mathrm{ab}$ & $1,260.60 \mathrm{ab}$ \\
Petaling 2 & $17.79 \mathrm{~b}$ & $792.50 \mathrm{~b}$ \\
Light intensities $(\%)$ & & \\
100 & $11.22 \mathrm{~b}$ & $523.30 \mathrm{~b}$ \\
75 & $44.70 \mathrm{a}$ & $1,927.20 \mathrm{a}$ \\
50 & $34.81 \mathrm{a}$ & $1,521.80 \mathrm{a}$ \\
Interaction & $(-)$ & $(-)$ \\
\hline
\end{tabular}

Note: Numbers followed by similar letters on the same column were not significantly different at $5 \%$ level. $(-)=$ No interaction

Table 7. Length, diameter, number, and length of internode on ortotroph branch as well as number, length and length of internode of plagiotroph branch on three varieties of black pepper at several light intensity levels

\begin{tabular}{|c|c|c|c|c|c|c|}
\hline Treatment & $\begin{array}{c}\text { Ortotrof } \\
\text { length }(\mathbf{c m})\end{array}$ & $\begin{array}{c}\text { Ortotorf } \\
\text { diameter } \\
(\mathrm{mm})\end{array}$ & $\begin{array}{c}\text { Ortotrof } \\
\text { internode length } \\
(\mathrm{cm})\end{array}$ & $\begin{array}{l}\text { Plagiotrof } \\
\text { number }\end{array}$ & $\begin{array}{l}\text { Plagiotrof } \\
\text { length }(\mathrm{cm})\end{array}$ & $\begin{array}{c}\text { Plagiotrof } \\
\text { internode length } \\
(\mathrm{cm})\end{array}$ \\
\hline \multicolumn{7}{|l|}{ Varieties } \\
\hline Nyelungkup & $108.81 \mathrm{a}$ & $6.24 \mathrm{a}$ & $5.87 \mathrm{a}$ & $10.22 \mathrm{a}$ & $24.06 \mathrm{a}$ & $4.44 a$ \\
\hline Petaling 1 & $99.72 \mathrm{a}$ & $5.68 \mathrm{ab}$ & $5.51 \mathrm{a}$ & $9.78 \mathrm{a}$ & 19.47ab & $4.20 \mathrm{a}$ \\
\hline Petaling 2 & $67.47 \mathrm{~b}$ & $5.32 \mathrm{~b}$ & $5.39 \mathrm{a}$ & $7.22 \mathrm{a}$ & $15.00 \mathrm{~b}$ & $4.35 \mathrm{a}$ \\
\hline \multicolumn{7}{|c|}{ Light intensities (\%) } \\
\hline 100 & $31.28 b$ & $4.83 b$ & $3.87 \mathrm{~b}$ & $4.50 \mathrm{~b}$ & $11.22 \mathrm{~b}$ & $3.52 \mathrm{a}$ \\
\hline 75 & $99.56 \mathrm{a}$ & $6.53 \mathrm{a}$ & $6.40 \mathrm{a}$ & $12.00 \mathrm{a}$ & $24.58 \mathrm{a}$ & $4.66 a$ \\
\hline 50 & $77.61 \mathrm{a}$ & $5.88 \mathrm{ab}$ & $6.51 \mathrm{a}$ & $10.72 \mathrm{a}$ & $22.72 \mathrm{a}$ & $4.80 \mathrm{a}$ \\
\hline Interaction & $(-)$ & $(-)$ & $(-)$ & $(-)$ & $(-)$ & $(-)$ \\
\hline
\end{tabular}

Note: Numbers followed by similar letters on the same column were not significantly different at $5 \%$ level. $(-)=$ No interaction 


\section{Net assimilation rate and crop growth rate}

Nett assimilation rate and crop growth rate were not influenced by interaction of variety and light intensity levels. The net assimilation rate of the three varieties tested was not significantly different but the growth rate was significantly different. The highest crop growth rate was noted on Nyelungkup variety, while the lowest ones were found on variety of Petaling 2 but they were not significantly different from those of Petaling 1 variety. Light intensity levels had merely impact on crop growth rate while nett assimilation rate was not significantly different among light intensity levels (Table 9). Light intensity of $75 \%$ increased the crop growth rate but low light intensity of $50 \%$ caused the crop growth rate decreased however it was not significantly different with that of $75 \%$ light intensity. Crop growth rate was related to number of assimilates produced by a plant. Leaf area was one of important factors in producing assimilates. The larger leaf area was produced by Nyelungkup variety and on the treatment of light intensities of $50 \%$ to $75 \%$. Hence, under similar nett assimilation rates but different leaf areas, crop growth rate was different.

\section{Plant dry weight}

There was no interaction between variety and light intensity on dry weights of leaf, branch, root, and total. Three tested varieties had different dry weights of leaf, branch, root, and total. Variety of Nyelungkup had the highest dry weight, while the lowest one was found on variety of Petaling 2. The dry weight of Petaling 1 variety was not significantly different from that of Nyelungkup and Petaling 2 varieties. The dry weights of leaf, branch, root, and total were significantly different among light intensity levels but ratio of root and shoot was not different. The dry weight of plants exposed to $50 \%$ and $75 \%$ light intensity was higher and significantly different from plants exposed to $100 \%$ light intensity. The results showed that black pepper needs a light shade so that its growth optimal, however light intensity is less than $50 \%$ decrease plant growth. Maximum dry weight was produced at $75 \%$ light intensity. Plant dry weight showed decreasing trend at light intensity of $50 \%$ but it was not significantly different from that at $75 \%$ light intensity. The dry weight of plants exposed to light intensity of $75 \%$ increased three folds of the dry weight of plants exposed to light by $100 \%$ while its exposed to light intensity of 50\% increased 2 folds (Table 10). Total plant dry weight was related to leaf area and NAR. The $75 \%$ light intensity produced the highest leaf area and NAR so that the produced total dry weight was higher. Similarly, variety of Nyelungkup had higher leaf area and NAR so that its dry weight was higher than that of Petaling 1 and Petaling 2 varieties.

\section{Correlation of hormones with plant morphology Branch}

Hormones had important roles in the growth of ortotroph and plagiotroph branches. It was indicated by the value of coefficient correlation between hormone and branch. Correlation analysis revealed that auxin had positive correlation with length of ortotroph branch $(\mathrm{r}=$ $0.4938 * *)$, diameter of ortotroph branch $(\mathrm{r}=0.5572 * *)$, number of internode on ortotroph branch $\left(\mathrm{r}=0.3478^{*}\right)$ and length of internode on ortotroph branch $\left(\mathrm{r}=0.5408^{* *}\right)$. Auxin was also positively correlated with number of plagiotroph branch $\left(\mathrm{r}=0.5408^{* *}\right)$, length of plagiotroph branch $(\mathrm{r}=0.4962 * *)$ and length of internode on plagiotroph branch $(\mathrm{r}=3418 *)$. Gibberellin was only positively correlated with number of ortotroph branches $(\mathrm{r}$ $\left.=0.3129^{*}\right)$ and number of plagiotroph branches $(\mathrm{r}=$ $0.3278 *$ ) (Table 4).

Table 9. Net assimilation rate (NAR) and crop growth rate (CGR) on three varieties of black pepper at several light intensity levels

\begin{tabular}{|c|c|c|}
\hline Treatment & $\begin{array}{c}\text { NAR } \\
\left(\mathrm{mg} \mathrm{dm}^{-2} \text { Week }^{-1}\right) \\
\end{array}$ & $\begin{array}{c}\text { CGR } \\
\left(\mathrm{g} \mathrm{m}^{-2} \text { Week }^{-1}\right) \\
\end{array}$ \\
\hline \multicolumn{3}{|l|}{ Varieties } \\
\hline Nyelungkup & $4.89 a$ & $10.79 a$ \\
\hline Petaling 1 & $3.33 \mathrm{a}$ & $6.28 \mathrm{ab}$ \\
\hline Petaling 2 & $2.67 \mathrm{a}$ & $4.65 \mathrm{~b}$ \\
\hline \multicolumn{3}{|c|}{ Light intensities (\%) } \\
\hline 100 & $4.00 \mathrm{a}$ & $2.91 \mathrm{~b}$ \\
\hline 75 & $3.67 \mathrm{a}$ & $10.89 \mathrm{a}$ \\
\hline 50 & $3.22 \mathrm{a}$ & 7.94ab \\
\hline Interaction & $(-)$ & $(-)$ \\
\hline
\end{tabular}

Note: Numbers followed by similar letters on the same column were not significantly different at $5 \%$ level. $(-)=$ No interaction

Table 10. Dry weights of the leaf. branch, root, shoot, and total as well as the ratio of root shoot on three varieties of black pepper at several light intensity levels

\begin{tabular}{lcccccc}
\hline \multicolumn{1}{c}{ Treatment } & $\begin{array}{c}\text { Leaf dry } \\
\text { weight }(\mathbf{g})\end{array}$ & $\begin{array}{c}\text { Branch dry } \\
\text { weight (g) }\end{array}$ & $\begin{array}{c}\text { Root dry } \\
\text { weight (g) }\end{array}$ & $\begin{array}{c}\text { Shoot dry } \\
\text { weight (g) }\end{array}$ & $\begin{array}{c}\text { Total dry } \\
\text { weight (g) }\end{array}$ & $\begin{array}{c}\text { Root shoot } \\
\text { ratio }\end{array}$ \\
\hline Varieties & & & & & & \\
Nyelungkup & $20.14 \mathrm{a}$ & $18.91 \mathrm{a}$ & $2.80 \mathrm{a}$ & $39.06 \mathrm{a}$ & $41.86 \mathrm{a}$ & $0.074 \mathrm{a}$ \\
Petaling 1 & $14.52 \mathrm{ab}$ & $15.75 \mathrm{ab}$ & $1.91 \mathrm{ab}$ & $30.27 \mathrm{ab}$ & $32.18 \mathrm{ab}$ & $0.059 \mathrm{a}$ \\
Petaling 2 & $9.88 \mathrm{~b}$ & $9.98 \mathrm{~b}$ & $1.11 \mathrm{~b}$ & $19.86 \mathrm{~b}$ & $20.97 \mathrm{~b}$ & $0.052 \mathrm{a}$ \\
Light intensities (\%) & & & & & & \\
100 & $6.43 \mathrm{~b}$ & $6.85 \mathrm{~b}$ & $0.70 \mathrm{~b}$ & $13.27 \mathrm{~b}$ & $13.98 \mathrm{~b}$ & $0.054 \mathrm{a}$ \\
75 & $22.34 \mathrm{a}$ & $20.25 \mathrm{a}$ & $3.05 \mathrm{a}$ & $42.58 \mathrm{a}$ & $45.63 \mathrm{a}$ & $0.072 \mathrm{a}$ \\
50 & $15.78 \mathrm{a}$ & $17.55 \mathrm{a}$ & $2.07 \mathrm{a}$ & $33.33 \mathrm{a}$ & $35.40 \mathrm{a}$ & $0.059 \mathrm{a}$ \\
Interaction & $(-)$ & $(-)$ & $(-)$ & $(-)$ & $(-)$ & $(-)$ \\
\hline
\end{tabular}

Note: Numbers followed by similar letters on the same column were not significantly different at $5 \%$ level. $(-)=$ No interaction 
Table 11. The value of Pearson coefficient correlation of auxin and gibberellin with morphological characteristics of black pepper

\begin{tabular}{lll}
\hline Parameter & Auxin & Gibberellin \\
\hline Leaf number & $0.5168^{* *}$ & $0.3258^{*}$ \\
Total leaf area & $0.4938^{* *}$ & $0.3699^{* *}$ \\
Leaf area index & $0.4938^{* *}$ & $0.3699^{* *}$ \\
Number of ortotroph branch & 0.1589 & $0.3129^{*}$ \\
Length of ortotroph & $0.3769^{* *}$ & -0.0832 \\
Number of internode on ortotroph branch & $0.3478^{*}$ & -0.1049 \\
Length of internode on ortotroph branch & $0.5408^{* *}$ & 0.0636 \\
Diameter of ortotroph branch & $0.5572^{* *}$ & 0.2972 \\
Number of plagiotroph branch & $0.5408^{* *}$ & $0.3278^{*}$ \\
Length of plagiotroph branch & $0.4962^{* *}$ & 0.0778 \\
Length of internode on plagiotroph branch & $0.3418^{*}$ & 0.0340 \\
Length of root & $0.4304^{* *}$ & 0.2973 \\
Root surface area & $0.3995^{* *}$ & 0.2672 \\
\hline
\end{tabular}

Note: (*) Significant correlation at $1 \%$ level (**) Significant correlation at 5\% level

These values exhibited that auxin had larger effect on the growth of branch than gibberellin. Such findings were also reported by Wang et al. (2014) that the elongation of branch on shaded-sweet potato was enhanced by auxin. However, according to Stamm and Kumar (2010), auxin and gibberellin were synergizing each other in controlling the growth of branch, especially under low light intensity.

\section{Leaf}

Leaf was formed in apical meristem of shoot so that it was affected by the activities of auxin and gibberellin. Correlation analysis revealed that auxin was positively correlated with leaf number $\left(\mathrm{r}=0.5168^{* *}\right)$, total leaf area $\left(\mathrm{r}=0.4938^{* *}\right)$ and leaf area index $\left(\mathrm{r}=0.4938^{* *}\right)$. Similarly, gibberellin was also positively correlated with leaf number $\left(\mathrm{r}=0.3258^{*}\right)$, total leaf area $\left(\mathrm{r}=0.3699^{* *}\right)$ and leaf area index $\left(\mathrm{r}=0.3699^{* *}\right)$ (Table 11). Like the branch, based on the value of coefficient correlation, auxin had larger impact on the formation and growth of leaf. However, auxin and gibberellin were synergizing each other in the formation and growth of leaf as reported by Wu et al. (2017).

\section{Root}

The growth of root was only influenced by auxin. It was indicated by the correlation between auxin and root morphology. Length of root and root area surface were positively correlated with auxin $(\mathrm{r}=0.4304 * *$ and $\mathrm{r}=$ $0.3995^{* *}$ ) (Table 11).

The research found that three varieties of black pepper tested, given the same responses on all light intensity levels. The varieties of Nyelungkup and Petaling 1 generated the best growth. Full light intensity inhibits the growth of black pepper. Light intensity up to $50 \%$ increased the leaf formation as well as the growth of branch and root. However, the maximum value was obtained at $75 \%$ light intensity. The growth of leaf, branch, and root was controlled by indigenous of auxin synergizing with gibberellin.

\section{ACKNOWLEDGEMENTS}

The grateful expression was delivered to the Indonesian Agricultural Agency for Research and Development, Ministry of Agriculture for financial support of this study.

\section{REFERENCES}

Cagnola JI, Edmundo P, Tomás BA, Scott AF, Casal JJ. 2012. Stem transcriptome reveals mechanisms to reduce the energetic cost of shade-avoidance responses in tomato. Plant Physiol 160: 1110-1119.

Casal J. 2012. Shade Avoidance. The Arabidopsis Book 10: e0157. DOI: 10.1199/tab.0157.

Casal J. 2013. Photoreceptor signaling networks in plant responses to shade. Ann Rev Plant Biol. 64: 8.1-8.25

Gommers CM, Visser EJ, StongeKR, Voesenek LA, Pierik R. 2013. Shade tolerance: when growing tall is not an option. Trends Plant Sci 18: $65-71$.

Gong WZ, Jiang CD, Wu YS, Chen HH, Liu WY, Yang WY. 2015. Tolerance vs. avoidance: two strategies of soybean (Glycine max) seedlings in response to shade in intercropping. Photosynthetica. 53: 259-268.

Gonzalez CV, Jofrea MF, Vila HF, Stoffel M, Bottini R, Giordano CV. 2016. Morphology and hydraulic architecture of Vitis vinifera L. cv. Syrah and TorronteÂs Riojano. PLoS ONE 11 (12): e0167767. DOI: 10.1371/journal.pone.0167767.

Halliday KJ, Martı'nez-Garc1'a JF, Josse E-M. 2009. Integration of light and auxin signaling. Cold Spring Harb Perspect Biol 1 (6): a001586. DOI: $10.1101 /$ cshperspect.a001586.

Hammerton RD, Bjorn N, Elisabeth T. 1998. Irradiance-induced alterations of growth and cytokinins in Phaseolus vulgaris seedlings. Plant Growth Reg 25: 63-69

Kamiya Y, García-Martínez JL. 1999. Regulation of gibberellin biosynthesis by light. Curr Opin Plant Biol 2: 398-403.

Kim SJ, Yu DJ, Kim TC, Lee HL. 2011. Growth and photosynthetic characteristics of blueberry (Vaccinium corymbosum cv. Bluecrop) under various shade levels. Scient Hort 129: 486-492.

Kohler KH, Marianne D, Gbring H. 1980. The influence of light on the cytokinin content of Amaranthus seedlings. Biol Plant 22 (2): 128134.

Li L, Karin L, Ghislain B, Robert JS, Jose PP, Chris CZ, Benjamin JC, Lauren JI, Ullas VP. 2012. Linking photoreceptor excitation to changes in plant architecture. Genes Dev 26: 785-790.

Linskens HF, Jackson JF. 1987. High-performance liquid chromatography in plant sciences. Springer-Verlag, Berlin. 
Martinez-Garcia J, Galstyan F, Salla-Martret A, Cifuentes-Esquivel M, Gallemí NM, Bou-Torrent J. 2010. Regulatory components of shade avoidance syndrome. Adv Bot Res 53: 65-116.

Nair KPP. 2011. Agronomy and Economy of Black Pepper and Cardamom: The "King" and "Queen" of Spices. Elsevier, Nederlands.

Possart A, Christian F, Andreas H. 2014. Shedding (far-red) light on phytochrome mechanisms and responses in land plants. Plant Sci 217 218: $36-46$

Stamm P, Kumar PP. 2010. The Phytohormone signal network regulating elongation growth during shade avoidance. J Exp Both 61 (11): 28892903.

Tao Y, Ferrer J-L, Ljung K, Pojer F, Hong F, Long JA, Li L, Moreno JE, Bowman ME, Ivans LJ, Cheng Y, Lim J, Zhao Y, Ballare CL, Sandberg G, Noel JP, Chory J .2008. Rapid synthesis of auxin via a new tryptophan-dependent pathway is required for shade avoidance in plants. Cell 133: 164-176.

Wahid P. 1984. The Effect of Shade and Fertilization on The Growth and Production of Black Pepper. [Dissertation]. Bogor Agriculture University, Bogor. [Indonesian]
Wang Q, Hou F, Dong S, Xie.B, Li A, Zhang H, Zhang L. 2014. Effects of shading on the photosynthetic capacity. endogenous hormones and root yield in purple-fleshed sweetpotato (Ipomoea batatas (L.) Lam). Plant Growth Regul 72: 113-122.

Wu Y, Gong W, Yang W. 2017. Shade inhibits leaf size by controlling cell proliferation and enlargement in soybean. Sci Rep 7 (9259): 1-10. Yamaguchi S, Smith MW, Brown RGS, Kamiya Y, Sun TP. 1998. Phytochrome regulation and differential expression of gibberellin $3^{\beta_{-}}$ hydroxylase genes in germinating Arabidopsis seeds. Plant Cell 10: 2115-2126.

Yudianto, Rizali A, Munif A, Setiadi D, Qoyim I. 2014. Environmental factor affecting productivity of two Indonesian varieties of black pepper (Piper nigrum L.). Agrivita 36 (3): 278-284.

Zdarska M, Tereza D, Zuzana G, Markéta P, Siarhei D, Jan H. 2015. Illuminating light, cytokinin, and ethylene signalling crosstalk in plant development. J Exp Both 66 (16): 4913-4931. 